\title{
Autocrine interaction between IL-5 and IL-1 $\beta$ mediates altered responsiveness of atopic asthmatic sensitized airway smooth muscle
}

\author{
Hakon Hakonarson, Neil Maskeri, Carrie Carter, Sing Chuang, and Michael M. Grunstein
}

Division of Pulmonary Medicine, Joseph Stokes, Jr. Research Institute, The Children's Hospital of Philadelphia, University of Pennsylvania School of Medicine, Philadelphia, Pennsylvania 19104, USA

Address correspondence to: Michael M. Grunstein, Division of Pulmonary Medicine, The Children's Hospital of Philadelphia, University of Pennsylvania School of Medicine, 34th Street and Civic Center Boulevard, Philadelphia,

Pennsylvania 19104, USA. Phone: (215) 590-3497; Fax: (215) 590-1397; E-mail: grunstein@email.chop.edu.

Received for publication April 20, 1999, and accepted in revised form July 22, 1999.

T-helper type 2 (Th2) cytokines have been implicated in the pathogenesis of the pulmonary inflammatory response and altered bronchial responsiveness in allergic asthma. To elucidate the mechanism of Th2-dependent mediation of altered airway responsiveness in the atopic asthmatic state, the expression and actions of specific cytokines were examined in isolated rabbit and human airway smooth muscle (ASM) tissues and cultured cells passively sensitized with sera from atopic asthmatic patients or nonatopic/nonasthmatic (control) subjects. Relative to control tissues, the atopic asthmatic sensitized ASM exhibited significantly enhanced maximal isometric contractility to acetylcholine and attenuated relaxation responses to isoproterenol. These proasthmatic changes in agonist responsiveness were ablated by pretreating the atopic sensitized tissues with either an IL-5 receptor blocking antibody (IL-5ra) or the human recombinant IL-1 receptor antagonist (IL-1ra), whereas an IL-4 neutralizing antibody had no effect. Moreover, relative to controls, atopic asthmatic sensitized ASM cells demonstrated an initial, early (after 3 hours of incubation) increased mRNA expression and protein release of IL-5. This was followed (after 6 hours of incubation) by an enhanced mRNA expression and release of IL-1 $\beta$ protein, an effect that was inhibited in sensitized cells pretreated with IL-5ra. Extended studies demonstrated that naive ASM exposed to exogenously administered IL-5 exhibited an induced upregulated mRNA expression and protein release of IL-1 $\beta$ associated with proasthmatic-like changes in ASM constrictor and relaxant responsiveness, and that these effects were ablated in tissues pretreated with IL-1ra. Taken together, these observations provide new evidence that (a) the Th2 cytokine IL-5 and the pleiotropic proinflammatory cytokine IL-1 $\beta$ are endogenously released by atopic asthmatic sensitized ASM and mechanistically interact to mediate the proasthmatic perturbations in ASM responsiveness; and (b) the nature of this interaction is given by an initial endogenous release of IL-5, which then acts to induce the autologous release of IL-1 $\beta$ by the sensitized ASM itself, resulting in its autocrine manifestation of the proasthmatic phenotype.

J. Clin. Invest. 104:657-667 (1999).

\section{Introduction}

Exaggerated agonist-mediated bronchoconstriction, impaired $\beta$-adrenoceptor-mediated airway relaxation, and airway inflammation, the latter principally involving infiltration of the airways with eosinophils, lymphocytes, and mast cells, are all characteristic features of the pathobiology of bronchial asthma (1-4). Whereas the mechanism(s) underlying these inflammationassociated changes in airway responsiveness remains largely unknown, atopy has been identified as a principal causative factor of asthma, as reflected by relatively enhanced serum IgE levels and predominant T-helper type 2 (Th2) cytokine responses following exposure to common allergens. Accordingly, the Th2 cytokines, principally including IL-4 and IL-5, have been implicated in mediating various proinflammatory humoral and cellular responses in atopic asthma. These include IL4-directed immunoglobulin isotope switching to $\operatorname{IgE}$ synthesis and IL-5-mediated eosinophil differentiation, recruitment, and activation (5-9). Thus, the combined actions of these Th2 cytokines have been mechanistically linked to IgE-coupled proinflammatory changes in airway responsiveness that characterize the atopic asthmatic phenotype. Indeed, in extended support of this concept, there is substantial evidence that IL-5 acts as a central mediator in the induction of altered airway responsiveness in asthma (10-12).

Whereas the elaboration of Th2 cytokines is principally attributed to the activation of mononuclear leukocytes, most notably $\mathrm{CD} 4^{+} / \mathrm{Th} 2$ lymphocytes, recent reports have demonstrated that certain nonbone marrow-derived resident tissue cells, including epithelial cells, keratinocytes, and other cell types, also have the capacity to express and respond to specific Th2 cytokines (13-16). In light of this evidence, together with new information demonstrating that 


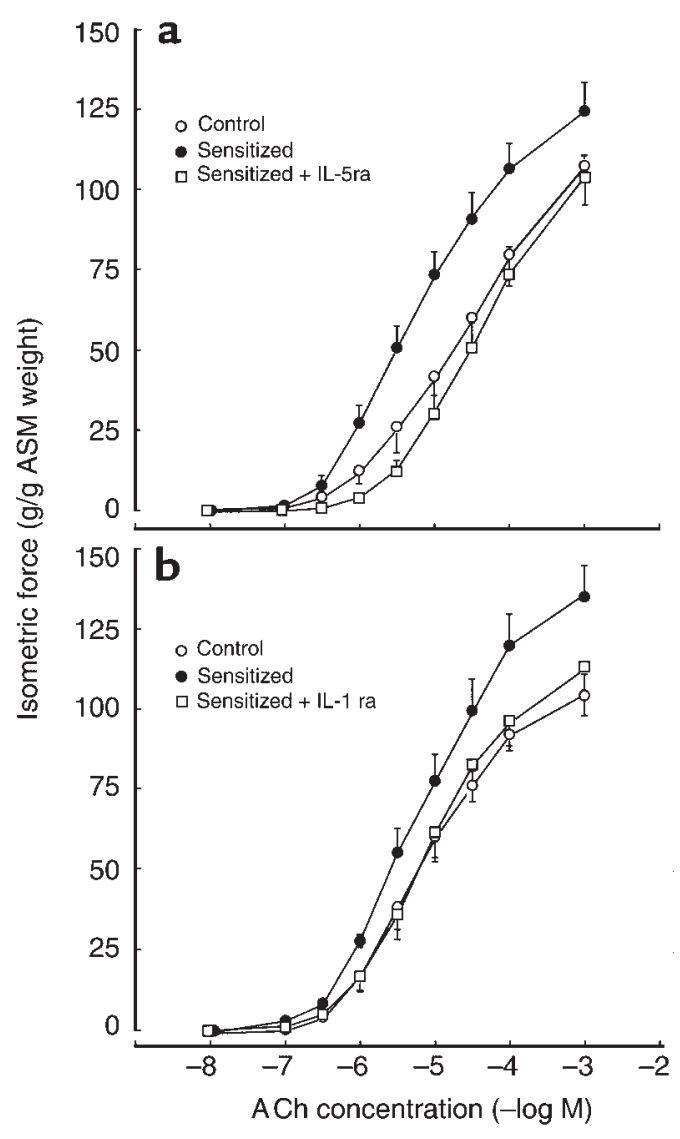

Figure 1

Comparison of contractile dose-response relationships to ACh in paired human control serum-treated (open circles) and human atopic asthmatic serum-treated rabbit ASM segments in the absence (closed circles) and presence (open squares) of maximum effective concentrations of IL-5ra (a) and IL-1 ra (b). Relative to controls, the heightened constrictor responses to ACh in the atopic asthmatic serum-sensitized tissues were prevented by cotreatment of tissues with either IL-5ra or IL-1ra. Data represent mean \pm SE values from 6 paired experiments.

the airway smooth muscle (ASM) itself can be induced to autologously express certain cytokines in the atopic asthmatic sensitized state, including IL-1 $\beta$ (17) and specific Th1 and Th2 cytokines (18), the present study examined the potential role and mechanisms of action of certain Th2 cytokines in regulating ASM responsiveness in the atopic asthmatic sensitized state. The results provide new evidence demonstrating that (a) the Th2 cytokine IL-5 and the pleiotropic proinflammatory cytokine IL-1 $\beta$ are endogenously released by atopic asthmatic sensitized ASM, and these cytokines mechanistically interact in mediating the altered constrictor and relaxant responsiveness in the sensitized ASM; and (b) the latter interaction is characterized by the initial release of IL-5, which then acts to upregulate the mRNA expression and endogenous release of IL- $1 \beta$ protein by the sensitized ASM itself, resulting in an autocrine manifestation of the proasthmatic phenotype of altered ASM responsiveness.

\section{Methods}

Animals. Twenty-six adult New Zealand white rabbits were used in this study, which was approved by the Biosafety and Animal Research Committee of the Joseph Stokes Research Institute at The Children's Hospital of Philadelphia. The animals had no signs of respiratory disease for several weeks before the study.

Preparation and sensitization of rabbit and human ASM tissue. Following general anesthesia with xylazine (10 $\mathrm{mg} / \mathrm{kg})$ and ketamine $(50 \mathrm{mg} / \mathrm{kg})$, rabbits were sacrificed with an overdose of pentobarbital $(130 \mathrm{mg} / \mathrm{kg})$. As described previously (18), the tracheae were removed using open thoracotomy; the loose connective tissue and epithelium were scraped and removed; and the tracheae were divided into 8 ring segments $6-8 \mathrm{~mm}$ long. Each alternate ring was incubated for 24 hours at room temperature in either (a) human serum containing more than $1,000 \mathrm{IU} / \mathrm{mL} \mathrm{IgE}$, obtained from allergic patients with moderate to severe asthma who are 4-5/6+ radioallergosorbent test-positive (RAST-positive; specific $\operatorname{IgE}$ concentration of $>17.5$ Phadebas RAST units [PRU] $/ \mathrm{mL}$ ) to Dermatophagoides pteronyssimus, Dermatophagoides farinae, and ragweed, and who have a positive skin test to these antigens; or (b) human serum from nonatopic nonasthmatic (control) individuals with normal serum IgE levels $(<70 \mathrm{IU} / \mathrm{mL})$ and negative skin test reactivity to $D$. pteronyssimus, $D$. farinae, and ragweed $(17,18)$. In parallel experiments, ASM segments were incubated in either control serum or atopic asthmatic serum in the absence and presence of maximum effective concentrations of either an anti-IL5 receptor neutralizing antibody (IL-5ra), an IL-4 neutralizing antibody, or the human recombinant IL-1 receptor antagonist (IL-1 ra). In addition, in separate experiments, ASM tissues were incubated in serum-free medium (SFM) with maximum effective concentrations of IL-5 $(5 \mathrm{ng} / \mathrm{mL})$ in the absence and presence of IL-1 ra $(140 \mathrm{ng} / \mathrm{mL})$. All the tissues studied were aerated with a continuous supplemental $\mathrm{O}_{2}$ mixture $(95 \%$ $\mathrm{O}_{2} / 5 \% \mathrm{CO}_{2}$ ) during the incubation phase.

In separate experiments, ASM tissue was isolated from 4 nonatopic nonasthmatic subjects who underwent lung resection for removal of a peripheral lung carcinoma. Tumor-free ASM tissue was carefully cleaned of its epithelium and loose connective tissue under a microscope, divided into several strips, and each alternate ASM strip was then incubated in SFM alone or in SFM in the presence of a maximum effective concentration of IL-5 $(5 \mathrm{ng} / \mathrm{mL})$ for varying time points. The tissues' mRNA and protein were subsequently isolated for analysis of cytokine expression (see below).

Preparation of cultured buman ASM cells. Cultured human ASM cells were obtained from Clonetics Corp. (San Diego, California, USA). The ASM cells were derived from 2 male donors, 16 and 21 years of age, who had no evidence of lung disease. The cells were carefully characterized by the manufacturer with specific markers to confirm their selective smooth muscle phenotype and to exclude any contamination with 
other cell types. The cells were grown in smooth muscle basal medium (SmBM) supplemented with 5\% FBS, insulin $(5 \mathrm{ng} / \mathrm{mL})$, EGF (10 $\mathrm{ng} / \mathrm{mL}$; human recombinant), FGF ( $2 \mathrm{ng} / \mathrm{mL}$; human recombinant), gentamycin $(50 \mathrm{ng} / \mathrm{mL})$, and amphotericin-B (50 ng/mL). The experimental protocol involved growing the cells to confluence in the above medium. Thereafter, the cells were starved in unsupplemented SmBM for 24 hours, at which time the cells were treated for $0,3,6$, and 24 hours with either human control serum, human atopic asthmatic serum, SFM alone, or SFM in the presence of a maximum effective concentration of IL-5. The cells were then examined for $\mathrm{mRNA}$ and protein expression of IL-5 and IL-1 $\beta$, as described below.

Pharmacodynamic studies. Following incubation of the rabbit ASM tissue preparations in control and atopic asthmatic serum, each airway segment was suspended longitudinally between stainless steel triangular supports in siliconized Harvard 20 - $\mathrm{mL}$ organ baths. The lower support was secured to the base of the organ bath, and the upper support was attached with a gold chain to a Grass FT.03C force transducer from which isometric tension was continuously displayed on a multichannel recorder. Care was taken to place the membranous portion of the trachea between the supports in order to maximize the recorded tension generated by the contracting trachealis muscle. The tissues were bathed in modified Krebs-Ringer solution containing (in mM) $125 \mathrm{NaCl}, 14 \mathrm{NaHCO}_{3}, 4 \mathrm{KCl}, 2.25$ $\mathrm{CaCl}_{2} \mathrm{H}_{2} \mathrm{O}, 1.46 \mathrm{MgSO}_{4} \mathrm{H}_{2} \mathrm{O}, 1.2 \mathrm{NaH}_{2} \mathrm{PO}_{4} \mathrm{H}_{2} \mathrm{O}$, and 11 glucose. The baths were aerated with $5 \% \mathrm{CO}_{2}$ in $\mathrm{O}_{2}$; a $\mathrm{pH}$ of 7.35-7.40 was maintained, and the organ bath temperature was held at $37^{\circ} \mathrm{C}$. Passive resting tension of each ASM segment was set at 1.5-2.0 g after the tissue had been passively stretched to a tension of $8 \mathrm{~g}$ in order to optimize its resting length for contraction (Lo), as described previously by our laboratory (19). The tissues were allowed to equilibrate in the organ baths for 45 minutes, at which time each tissue was primed with a 1-minute exposure to $10^{-4} \mathrm{M}$ acetylcholine (ACh). Cholinergic contractility was subsequently assessed in the ASM segments by cumulative administration of ACh in final bath concentrations ranging from $10^{-10}$ to $10^{-3} \mathrm{M}$. Thereafter, in separate studies, relaxation dose-response curves to isoproterenol $\left(10^{-10}-10^{-4} \mathrm{M}\right)$ were conducted in tissues half-maximally contracted with ACh. The relaxant responses to isoproterenol were analyzed in terms of percent maximal relaxation $\left(\mathrm{R}_{\max }\right)$ from the initial level of active cholinergic contraction, and sensitivity to the relaxing agent was determined as the negative logarithm of the dose of the relaxing agent producing $50 \%$ of $\mathrm{R}_{\max }\left(\mathrm{pD}_{50}\right.$; i.e., geometric mean $\mathrm{ED}_{50}$ ).

Determination of IL-5 and IL-1 $\beta m R N A$ expression. Total RNA was isolated from the above tissue and cell preparations using the modified guanidinium thiocyanate phenol-chloroform extraction method to include proteinase $\mathrm{K}$ (in 5\% SDS) for digestion of protein in the initial RNA pellet, as previously described by our lab-

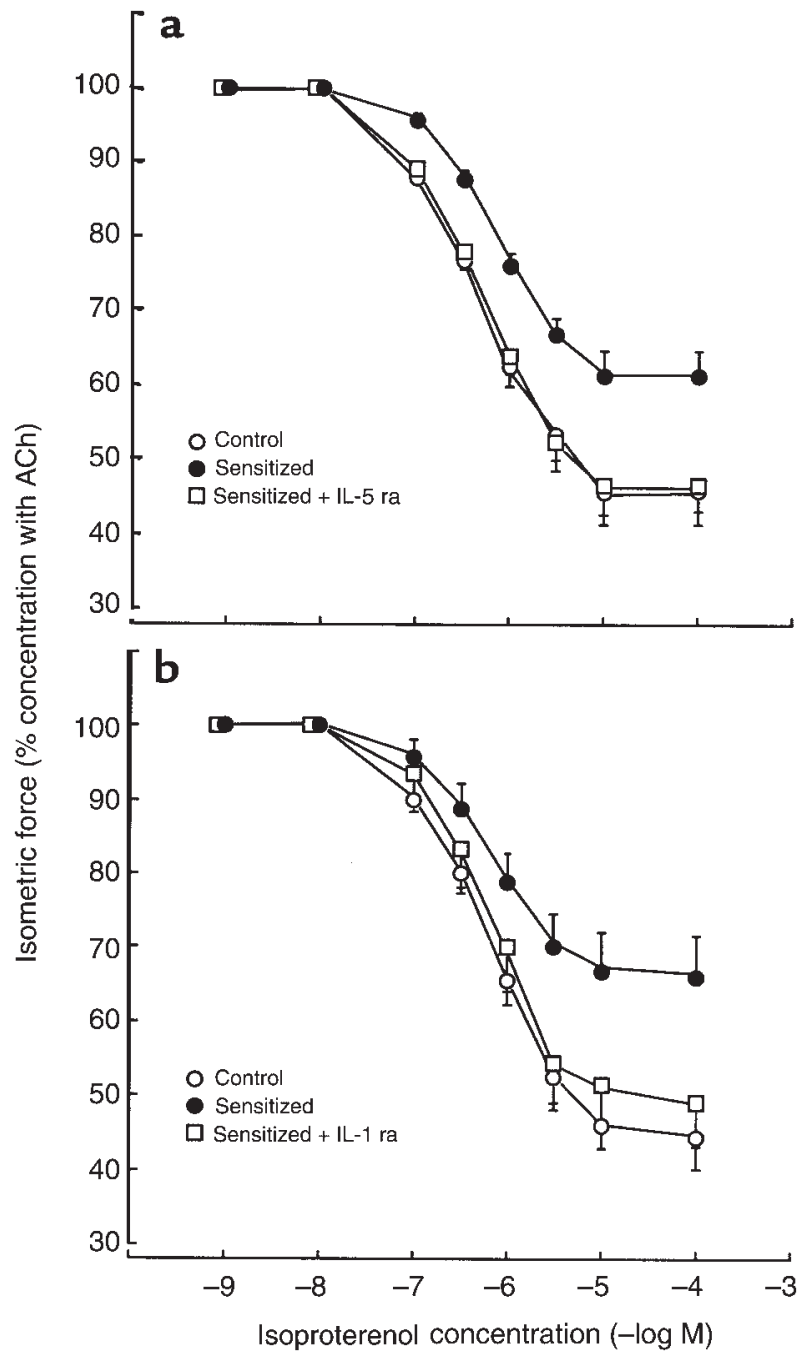

Figure 2

Comparison of relaxation dose-response relationships to isoproterenol in paired human control serum-treated (open circles) and human atopic asthmatic serum-treated rabbit ASM segments halfmaximally contracted with their respective $\mathrm{ED}_{50}$ doses of $A C h$ in the absence (filled circles) and presence (open squares) of maximum effective concentrations of IL-5ra (a) and IL-1 ra (b). Relative to controls, the attenuated relaxation responses to isoproterenol in the atopic asthmatic serum-sensitized tissues were prevented by cotreatment of tissues with either IL-5ra (a) or IL-1ra (b). Data represent mean \pm SE values from 6 paired experiments.

oratory $(17,20)$. The concentration of each RNA sample was determined spectrophotometrically. This procedure consistently produced yields of $15-25 \mu \mathrm{g}$ of intact RNA from each T-75 flask of HBSM cells and from each tissue specimen under study. To analyze for mRNA expression of IL- 5 and IL- $1 \beta$, we used an RTPCR protocol that included human-specific primers for these molecules, as well as for the constitutively expressed ribosomal protein (RP)L7. cDNA was synthesized from total RNA isolated from human ASM cells passively sensitized with human control or atopic asthmatic serum in the absence and presence of IL-5ra or IL-1ra, or in SFM with maximum effective concen- 

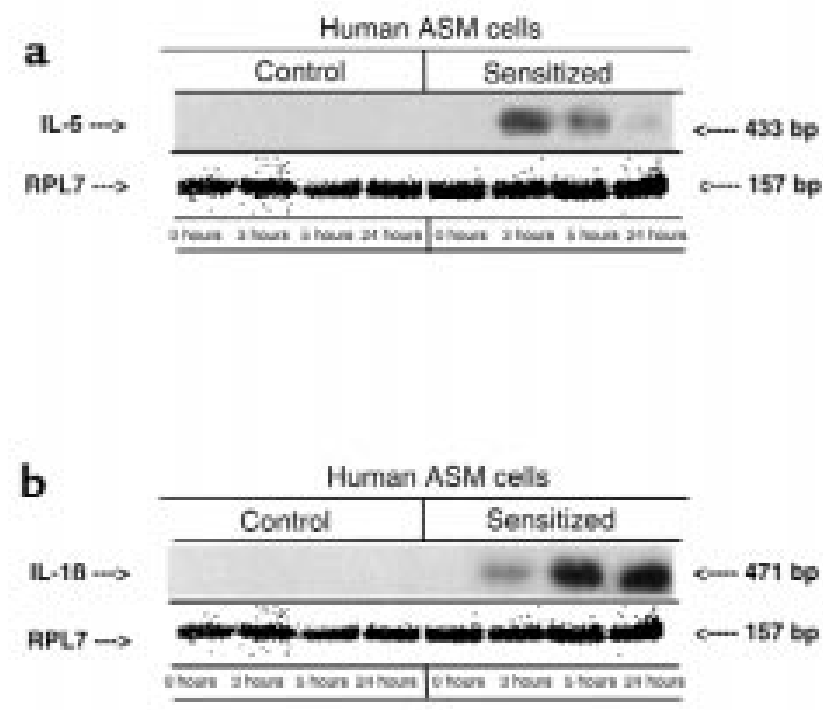

Figure 3

Comparison of expression of IL-5 (a) and IL-1 $\beta$ (b) mRNAs using RTPCR and Southern blot analysis in human ASM cells after 0-, 3-, 6-, and 24-hour exposure to human control serum and human atopic asthmatic serum. Expression of RPL7 mRNA was used to control for gel loading. The blots were probed with human specific IL-5, IL-1 and RPL7 ${ }^{32}$ P-labeled cDNA probes (see Methods). Whereas mRNA expression of IL-5 or IL-1 $\beta$ was unaltered in cells that were exposed to control serum, the mRNA signals for IL-5 and IL-1 $\beta$ were upregulated in cells that were exposed to atopic asthmatic serum. The temporal patterns of enhanced mRNA expression of these cytokines were characterized by an initial (at 3 hours) increased expression of IL-5 mRNA, followed (at 6 hours) by an increased mRNA expression of IL-1 $\beta$. In contrast, mRNA expression of the constitutively expressed RPL7 gene was unaltered.

trations of IL-5. cDNA from activated PBMCs served as positive controls for the IL- 5 and IL- $1 \beta$ expression analyses. The cDNA was primed with oligo-dT 12-18 and extended with Superscript II reverse transcriptase (GIBCO BRL, Gaithersburg, Maryland, USA). The PCR was used to amplify the specific products from each cDNA reaction, based on the published sequences of the human IL-5, IL- $1 \beta$, and RPL7 genes (21-23), and included the following primer sets. For IL-5: 5'-primer 5'-GTATGCCATCCCCACAGAAA-3', 3'-primer 5'-TACAGACATTCACAGCCACC-3' (product is $433 \mathrm{bp}$ ); for IL-1 $\beta: 5^{\prime}$-primer $5^{\prime}$-AGATGAAGTGCTCCTTCCAG-3', 3'-primer 5'-CAACACGCAGGACAGGTACAG- $3^{\prime}$ (product is $471 \mathrm{bp}$ ); RPL7: 5'-primer 5'-AAGAGGCTCTCATTTTCCTGGCTG-3', 3'-primer 5'-TCCGTTCCTCCCCATAATGTTCC-3' (product is $157 \mathrm{bp}$ ).

The cycling profile used was as follows: denaturation at $95^{\circ} \mathrm{C}$ for 1 minute; annealing at $52-55^{\circ} \mathrm{C}$ for 1.0 minute; and extension at $72^{\circ} \mathrm{C}$ for 1.0 minute with 34 cycles for the IL-5 and IL-1 $\beta$ genes and 26 cycles for the RPL7 gene. The number of cycles were determined to be in the linear range of the PCR products. The PCR reactions for the human IL-5, IL-1 $\beta$, and RPL7 primers were performed using equivalent amounts of cDNA prepared from $2.5 \mu \mathrm{g}$ of total RNA. Equal aliquots of each PCR reaction were then run on a $1.2 \%$ agarose gel and subsequently transferred to a Zeta-probe membrane, where it remained overnight in $0.4 \mathrm{~N} \mathrm{NaOH}$. Following capillary transfer, the DNA was immobilized by ultraviolet cross-linking using a Stratalinker UV Crosslinker 2400 at $120,000 \mu \mathrm{J} / \mathrm{cm}^{2}$ (Stratagene, La Jolla, California, USA). Prehybridization in a hybridization oven was conducted for $2-3$ hours at $42^{\circ} \mathrm{C}$ in $50 \%$ formaldehyde, $7 \%$ (wt/vol) SDS, $0.25 \mathrm{M} \mathrm{NaCl}, 0.12 \mathrm{M}$ $\mathrm{Na}_{2} \mathrm{HPO}_{4}(\mathrm{pH} 7.2$ ), and $1 \mathrm{mM}$ EDTA. Hybridization was for 20 hours at $42^{\circ} \mathrm{C}$ in the same solution. The IL5 , IL-1 $\beta$, and RPL7 DNA levels were assayed by Southern blot analysis using ${ }^{32} \mathrm{P}$-labeled probes, prepared by pooling several RT-PCR reactions for the individual IL5 , IL-1 $\beta$, and RPL7 PCR fragments and purifying them from a $1.2 \%$ agarose gel using the QIAEX II agarose gel extraction kit (QIAGEN Inc., Valencia, California, USA). The individual PCR products were subsequently sequenced for confirmation. Washes were as follows: 1 $\times 15$ minutes in $2 \times$ SSC, $0.1 \%$ SDS and $1 \times 15$ minutes in $0.1 \times \mathrm{SSC}, 0.1 \% \mathrm{SDS}$ (both at room temperature); and $2 \times 15$ minutes at $50^{\circ} \mathrm{C}$ in $0.1 \times$ SSC, $0.1 \%$ SDS. Southern blots were quantitated by direct measurements of radioactivity in each band using a PhosphorImager (Molecular Dynamics, Sunnyvale, California, USA).

ELISA measurements of IL-5 and IL-1 $\beta$ proteins. IL-5 and IL- $1 \beta$ protein levels were measured initially in the control and atopic asthmatic sera. Thereafter, the protein levels were assayed in the culture media of ASM cells that were exposed for $0,3,6$, and 24 hours to either the control serum or atopic asthmatic serum. IL- $1 \beta$ protein levels were also assayed in the culture media from human ASM cells at the same time points following treatment with SFM alone or with SFM containing a maximum effective concentration of IL-5. The IL-5 and IL-1 $\beta$ protein levels were quantitatively assessed using an enzyme-specific immunoassay, as described previously by our laboratory (17). The latter assay was performed using a double-antibody sandwich strategy in which an acetylcholine-esterase (AChE), Fab-conjugated IL-5 - or IL- $1 \beta$-specific secondary antibody is targeted to a first cytokine-captured antibody. The enzymatic activity of the AChE was measured spectrophotometrically, and, relative to a linear standard curve (range: $0-250 \mathrm{pg} / \mathrm{mL}$ ), the results were used to quantify the amount of the targeted IL-5 and IL- $1 \beta$ present in the cell culture media.

Determination of IL-1 $\beta$ protein expression by Western blot analysis. Expression of IL-1 $\beta$ protein was assayed by Western blot analysis of membrane protein lysate samples isolated from cultured human ASM cells and ASM tissues following 24-hour treatment with either SFM alone or SFM containing IL-5 $(5 \mathrm{ng} / \mathrm{mL})$. The protein lysate samples were homogenized and prepared in 40 volumes of $50 \mathrm{mM}$ Tris-HC1, $150 \mathrm{mM}$ $\mathrm{NaCl}, 1 \mathrm{mM}$ EDTA ( $\mathrm{pH}$ 7.4) containing $1 \mathrm{mM}$ phenylmethylsulfonyl fluoride, $5 \mu \mathrm{g} / \mathrm{mL}$ aprotinin, and 5 $\mu \mathrm{g} / \mathrm{mL}$ leupeptin. Nuclei and large particulates were 
removed by centrifugation at $100 \mathrm{~g}$ for 5 minutes. The supernatant was then salvaged, and the protein concentration was measured using the Lowry assay. Equivalent amounts $(30-50 \mu \mathrm{g})$ of membrane protein were fractionated in 9-11\% SDS-polyacrylamide gels, followed by transfer to nitrocellulose membranes. The membranes were then blotted overnight at room temperature in $25 \mathrm{mM}$ Tris- $\mathrm{HCl}(\mathrm{pH} 7.5), 150 \mathrm{mM} \mathrm{NaCl}$, and $0.05 \%$ Tergitol NP-40 containing $5 \%$ nonfat milk, as described previously by our laboratory (18). The primary mouse anti-human IL- $1 \beta$ antibody used was diluted 1:250 and incubated for 1-2 hours at room temperature. The primary and secondary antibody incubations and washes were done in $25 \mathrm{mM}$ Tris- $\mathrm{HCl}$ ( $\mathrm{pH} 7.5), 150 \mathrm{mM} \mathrm{NaCl}$, and $0.05 \% \mathrm{NP}-40$ containing $0.50 \%$ nonfat milk. The IL-1 $\beta$ protein levels were detected using enhanced chemiluminescence after a 1hour incubation with a 1:1,000 dilution of an antimouse horseradish peroxidase-linked secondary antibody and subsequent exposure to autoradiography film. The protein levels expressed were then quantitated using laser densitometry (Bio-Rad Laboratories Inc., Hercules, California, USA).

Statistical analysis. Statistical analysis was performed by means of the 2-tailed paired Student's $t$ test. $P$ values less than 0.05 were considered to be significant.

Reagents. The human airway tissue was provided by the Cooperative Human Tissue Network, which is funded by the National Cancer Institute. The human ASM cells and SmBM medium were obtained from Clonetics Corp. The IL-5, IL-1 $\beta$, and RPL7 primers were obtained from Integrated DNA Technologies Inc. (Coralville, Iowa, USA). The IL-1 receptor antagonist, anti-human IL-5 receptor and IL-4 neutralizing antibodies, IL-5 and IL-1 $\beta$ ELISA kits, mouse anti-human IL-1 $\beta$ primary antibody, and anti-mouse secondary antibody used in protein assay studies were purchased from R\&D Systems Inc. (Minneapolis, Minnesota, USA). ACh and isoproterenol were purchased from Sigma Chemical Co. (St. Louis, Missouri). All drug concentrations are expressed as final bath concentrations. Isoproterenol and $\mathrm{ACh}$ were made fresh for each experiment and were dissolved in normal saline to prepare stock solutions $\left(10^{-4} \mathrm{M}\right.$ for both).

\section{Results}

Roles of $I L-5$ and $I L-1 \beta$ in regulating ASM responsiveness in the atopic asthmatic sensitized state. Agonist-induced constrictor and relaxation responses were separately examined in isolated rabbit tracheal ASM segments that were incubated for 24 hours in either human atopic asthmatic serum or serum from nonatopic/nonasthmatic (i.e., control) individuals, both in the absence and presence of either a monoclonal neutralizing antibody to IL-4 (IL-4Nab), an IL-5 receptor blocking antibody (IL-5ra), or the endogenous IL-1 receptor antagonist (IL-1ra) (see Methods). As shown in Figure 1a, relative to control serum-treated tissues (open circles), the maximal con- strictor responses $\left(\mathrm{T}_{\max }\right)$ and sensitivities $\left(\mathrm{pD}_{50}\right.$; i.e., $-\log \mathrm{ED}_{50}$ values) to exogenously administered ACh were significantly enhanced in ASM passively sensitized with atopic asthmatic serum (filled circles). Accordingly, the mean $\pm \mathrm{SE}_{\max }$ values amounted to $112.1 \pm 5.2$ and $124.5 \pm 9.1 \mathrm{~g} / \mathrm{g}$ tracheal smooth muscle (TSM) in the control and atopic sensitized tissues, respectively $(P<0.01)$; and the corresponding mean $\mathrm{pD}_{50}$ values amounted to $4.83 \pm 0.04$ and $5.39 \pm 0.06$ $-\log \mathrm{M}$, respectively $(P<0.01)$. These induced augmented constrictor responses to ACh in atopic sensitized ASM were unaffected by pretreatment of the sensitized tissues with IL-4Nab (data not shown), and in these tissues the mean $\pm S E T_{\max }$ and $E_{50}$ values remained elevated at $127.3 \pm 7.1 \mathrm{~g} / \mathrm{g}$ TSM and $5.42 \pm$ $0.06-\log \mathrm{M}$, respectively. In contrast, the heightened constrictor responses to ACh were largely prevented in atopic asthmatic sensitized tissues that were pretreated with a maximally effective concentration (i.e., $50 \mathrm{ng} / \mathrm{mL}$ ) of IL-5ra (Figure 1a; open squares), wherein the mean $\pm \mathrm{SE} \mathrm{T}_{\max }$ and $\mathrm{pD}_{50}$ values amounted to $110.1 \pm 11.9 \mathrm{~g} / \mathrm{g}$ TSM and $4.93 \pm 0.05-\log \mathrm{M}$, respectively. The latter determinations were not significantly different from those obtained in the control serum-treated ASM tissues. Similarly, in comparable experiments, consistent with our earlier observations (17), we found that pretreatment of atopic asthmatic sensitized ASM with IL-1ra (140 ng/mL) also ablated the tissues' heightened constrictor responsiveness to

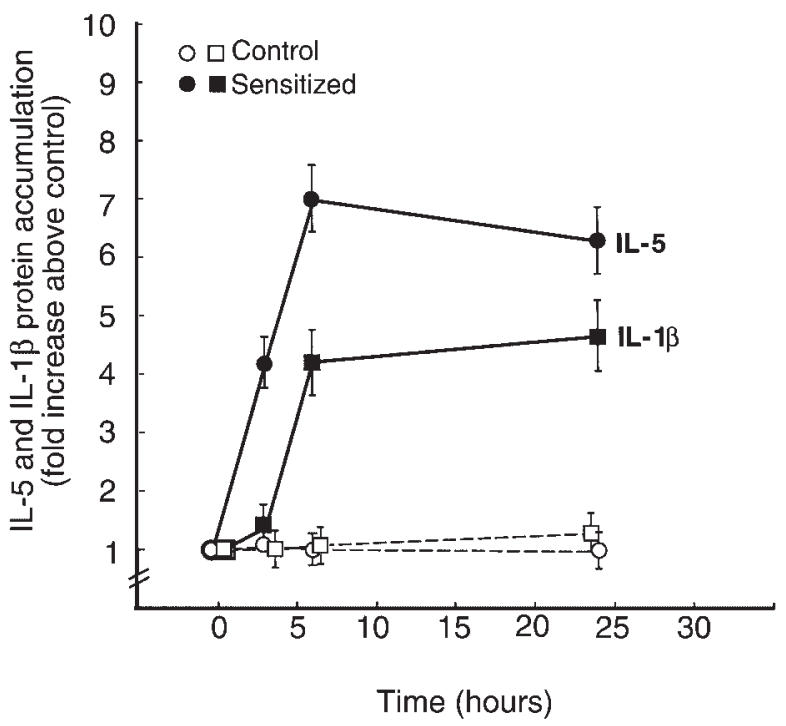

Figure 4

Comparisons of the release of IL- 5 and IL- $1 \beta$ proteins into the culture media of human ASM cells after 0-, 3-, 6-, and 24-hour exposure to human control serum (open symbols) and human atopic asthmatic serum (filled symbols). In contrast to control serum that had no appreciable effect, ASM cells exposed to human atopic asthmatic serum showed significantly increased levels of both IL-5 (filled circles) and IL-1 $\beta$ (filled squares) protein release into the cell culture media. Moreover, the temporal pattern for IL-5 release appeared relatively earlier (at 3 hours) than that for IL-1 $\beta$ release. Data represent mean \pm SE values. 


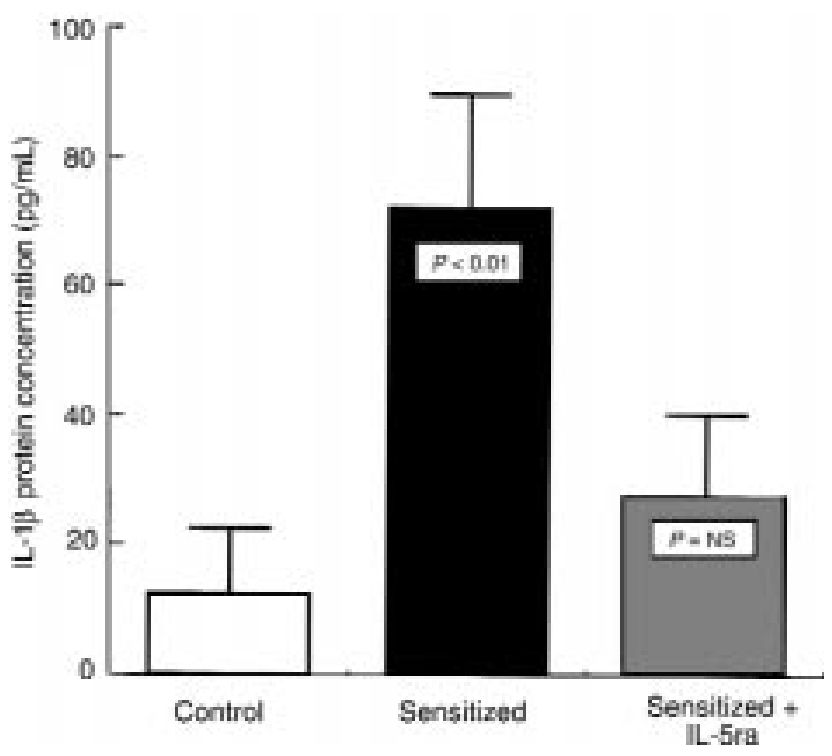

Figure 5

Comparison of IL-1 $\beta$ protein elaboration into the culture media of human ASM cells after 24-hour exposure to human control serum or human atopic asthmatic serum in the absence and presence of IL$5 \mathrm{ra}$. Relative to control serum-treated cells, atopic asthmatic serum-treated cells showed a significantly enhanced release of IL-1 $\beta$ into the cell culture medium, and the increase in IL-1 $\beta$ protein release was largely ablated in the atopic sensitized cells that were pretreated with IL-5ra. Data represent mean \pm SE values.

ACh (Figure 1b). Accordingly, the $T_{\max }$ values in the atopic sensitized vs. control tissues averaged $138.1 \pm$ 9.9 vs. $101.2 \pm 6.9 \mathrm{~g} / \mathrm{g}$ TSM, respectively $(P<0.01)$; the corresponding $\mathrm{pD}_{50}$ values averaged $5.72 \pm 0.05$ and $5.19 \pm 0.06-\log \mathrm{M}$, respectively $(P<0.05)$. In the presence of IL-1 ra, the $\mathrm{T}_{\max }$ and $\mathrm{pD}_{50}$ values in the sensitized ASM were similar to those obtained in the control serum-treated tissues and averaged $104.8 \pm 5.7$ $\mathrm{g} / \mathrm{g}$ TSM and $5.17 \pm 0.04-\log \mathrm{M}$, respectively. In contrast to these observations in atopic sensitized tissues, IL-4Nab, IL-5ra, and IL-1 ra had no appreciable effect on ASM constrictor responsiveness to ACh in control serum-exposed tissues (data not shown).

In separate studies, during comparable levels of initial ACh-induced contractions in control and atopic asthmatic sensitized ASM segments averaging approximately $40 \%$ of $\mathrm{T}_{\max }$, administration of the $\beta$-adrenergic receptor agonist, isoproterenol, elicited cumulative dose-dependent relaxation of the precontracted tissues. As shown in Figure 2a, relative to control serum-treated ASM (open circles), the maximal relaxation responses ( $\mathrm{R}_{\max }$ values) and sensitivities ( $\mathrm{pD}_{50}$ values) to isoproterenol were significantly attenuated in the corresponding atopic asthmatic sensitized tissues (filled circles). Accordingly, the mean $\pm \mathrm{SE} \mathrm{R}_{\max }$ value for isoproterenol amounted to $40.1 \pm 6.2 \%$ in the atopic sensitized ASM, compared with $55.5 \pm 6.3 \%$ in the control serum-treated ASM $(P<0.005)$; the corresponding $\mathrm{pD}_{50}$ values averaged $6.11 \pm 0.06$ and $6.47 \pm 0.07-\log \mathrm{M}$, respectively $(P<0.05)$. These attenuated relaxation responses to isoproterenol were unaffected in sensitized tissues pretreated with IL-4Nab, wherein the $\mathrm{R}_{\max }$ and $\mathrm{pD}_{50}$ values averaged $38.1 \pm 7.0 \%$ and $6.09 \pm 0.07-\log \mathrm{M}$, respectively (data not shown). In contrast, the impaired relaxation responses to isoproterenol were prevented in atopic asthmatic sensitized tissues that were pretreated with IL-5ra (Figure 2a; open squares), wherein the mean $\pm \mathrm{SE} \mathrm{R}_{\max }$ and $\mathrm{pD}_{50}$ values averaged $55.4 \pm 5.2 \%$ and 6.40 $\pm 0.06-\log M$, respectively. Similarly, in comparable experiments, the attenuated isoproterenol-induced relaxation responses were also ablated in atopic asthmatic sensitized ASM segments that were pretreated with IL-1ra (Figure 2b). Contrasting these observations obtained in atopic asthmatic sensitized ASM, in tissues incubated with control serum, we found that pretreatment with IL-4Nab, IL-5ra, and IL-1ra did not affect the tissues' subsequent relaxation responsiveness to isoproterenol (data not shown).

Interactive roles of IL-5 and IL-1 $\beta$ in atopic asthmatic sensitized ASM. Taken together, the above observations suggested that IL-5 and IL- $1 \beta$ may share a common or interactive mechanism in mediating the proasthmatic phenotypic changes in ASM responsiveness in the atopic sensitized state. In addressing this issue, we initially conducted a series of experiments that examined whether cultured human ASM cells express the mRNAs and proteins for the above cytokines, and further assessed whether the expressions of IL- 5 and IL- $1 \beta$ were altered in the atopic asthmatic sensitized state. For the mRNA analyses using RT-PCR and human IL-5- and IL-1 $\beta$-specific primers, cDNA was reverse-transcribed from total isolated RNA primed with oligo-dT or with random hexamers, and Southern blots were subsequently prepared and probed with the human cDNA probes specific for the human IL-5 and IL- $1 \beta$ genes (see Methods). In addition, a 157-bp ribosomal protein L7 (RPL7) probe was also used as a control for gel loading, and the signals for the individual PCR products were quantitated on a PhosphorImager. As depicted in Figure 3, exposure of cultured human ASM cells to atopic asthmatic sensitizing serum induced upregulated expression of both the IL-5 and IL- $1 \beta$ mRNA signals (Figure 3 , $a$ and $b$, respectively). Accordingly, in contrast to control serum-treated cells, wherein the intensities of the IL-5 and IL-1 $\beta$ mRNA signals were low or barely detectable, the mRNAs for both these cytokines were markedly induced in the atopic asthmatic sensitized cells, whereas the corresponding constitutively expressed RPL-7 signal remained essentially unaltered. In further examining Figure 3, a and $b$, it can be seen that although both the IL- 5 and IL$1 \beta$ mRNA signals were upregulated in the atopic sensitized ASM cells, the temporal patterns of enhanced mRNA expression of these cytokines were notably different. Thus, whereas IL-5 mRNA expression was clearly increased as early as 3 hours in the atopic sensitized cells, and the signal was subsequently attenuated by 24 hours, the corresponding IL- $1 \beta$ mRNA signal was more distinctly increased relatively later, at 6 hours, and remained enhanced thereafter at 24 hours in the sensitized cells. 
Given the above findings, in complementary studies using cytokine-specific RIAs (see Methods), we examined whether the above temporal changes in IL-5 and IL-1 $\beta$ mRNA expression are also reflected by corresponding changes in the release of these cytokine proteins into the culture media of human ASM cells exposed to control and atopic asthmatic serum. The basal concentrations of IL-5 protein in the control and atopic asthmatic sera averaged $3.01 \pm 0.37$ and $4.34 \pm$ $1.84 \mathrm{pq} / \mathrm{mL}$, respectively; the concentrations of IL- $1 \beta$ averaged $10.15 \pm 2.72$ and $12.14 \pm 1.95 \mathrm{pg} / \mathrm{mL}$, respectively. The concentrations of these cytokines were then assayed in the culture medium within approximately 30 minutes of exposure of the cells to the sera (baseline), and thereafter, following 3, 6, and 24 hours of serum incubation. The basal levels of IL- 5 and IL-1 $\beta$ protein in the culture media averaged $1.65 \pm 0.28$ and $8.35 \pm 3.7 \mathrm{pg} / \mathrm{mL}$, respectively. As shown in Figure 4, these levels did not significantly change in cells exposed to control serum (open symbols) for up to 24 hours. In contrast, the IL-5 (filled circles) and IL- $\beta$ (filled squares) protein levels progressively increased in the culture media of the atopic asthmatic sensitized cells, reaching maximal levels of approximately 7 - and 4-fold above their respective basal levels, and remained elevated at 24 hours. In comparing the temporal patterns of IL-5 and IL-1 $\beta$ protein release, it will be seen that, apart from a relatively enhanced maximal proportional increase in IL- 5 relative to IL-1 $\beta$, the atopic sensitized cells showed an earlier release of IL-5 protein (at 3 hours), whereas the release of IL- $1 \beta$ protein was largely delayed until 6 hours after exposure to the sensitizing serum. Of note, these temporal differences in IL-5 and IL- $1 \beta$ protein release by the sensitized ASM cells parallel the different temporal patterns of enhanced mRNA expression of these cytokines (Figure 3).

In light of the above observations, and given the substantial evidence in earlier independent studies that implicated a role for either IL-5 (10-12) or IL-1 $\beta$ (17, 24-26) in the induction of altered airway responsiveness following antigen challenge in various animal models, we next examined whether the above changes in IL-5 and IL- $1 \beta$ expression in the atopic asthmatic sensitized state are causally and specifically related. Accordingly, in studies using cultured human ASM cells, levels of IL-1 $\beta$ protein accumulation in the cell culture media were assayed after 24-hour exposure of the cells to control serum or atopic asthmatic serum in the absence and presence of IL-5ra and IL-4Nab. As shown in Figure 5, relative to control serum-treated cells, atopic asthmatic serum-sensitized cells demonstrated a significantly enhanced release of IL- $1 \beta$ protein into the cell culture medium. Moreover, it will be noted that the enhanced IL- $1 \beta$ release was largely ablated in the atopic sensitized cells that were pretreated with IL$5 \mathrm{ra}(50 \mathrm{ng} / \mathrm{mL})$. Contrasting this effect of IL-5ra, pretreatment of atopic sensitized cells with IL-4Nab had no significant effect on the augmented release of IL-1 $\beta$ protein (data not shown).
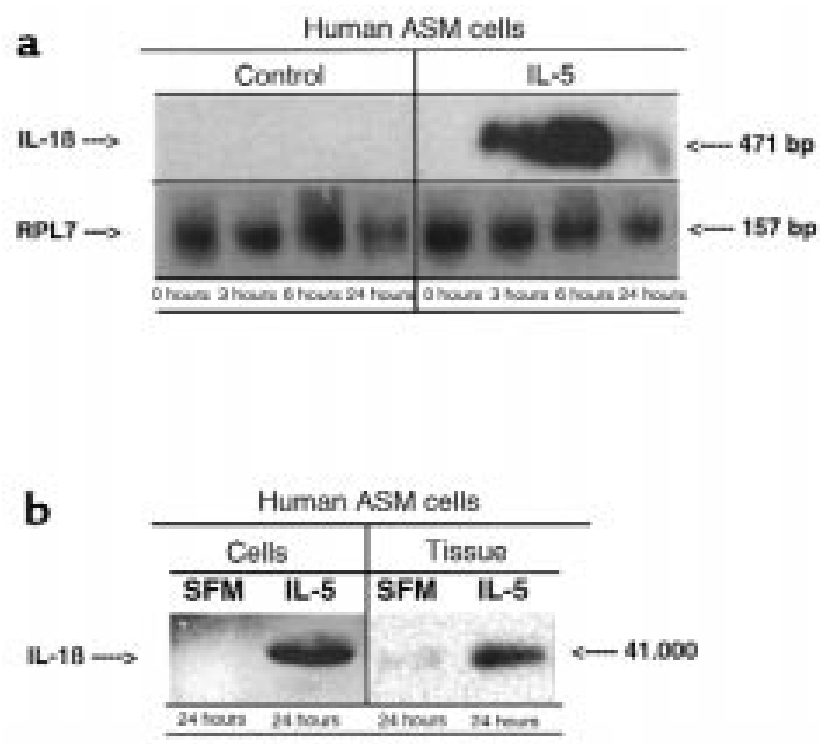

\section{Figure 6}

(a) Comparison of human IL-1 $\beta$ mRNA expression examined using RT-PCR and Southern blot analysis in cultured human ASM cells after 0-, 3-, 6-, and 24-hour exposure to SFM alone (control) or IL5. Relative to the unaltered constitutively expressed RPL7 mRNA signal, IL-1 $\beta$ mRNA expression was markedly upregulated at 3 and 6 hours in the IL-5-exposed ASM cells, whereas the IL-1 $\beta$ mRNA signal was virtually undetectable in the control cells. (b) Western blot analyses of human IL-1 $\beta$ expression in membrane/lysate samples isolated from cultured human ASM cells and tissues after 24-hour exposure to SFM alone and to IL-5. In contrast to control cells and tissues maintained in SFM alone, the cells and tissues treated with IL-5 exhibited markedly upregulated expression of IL-1 $\beta$ protein.

In a complementary series of experiments, we next investigated the effects of exogenous IL-5 administration on IL-1 $\beta$ mRNA and protein expression, both in human cultured ASM cells and human ASM tissue preparations. As shown in Figure 6a, in contrast to control cells maintained in SFM alone, cells treated with IL-5 $(5 \mathrm{ng} / \mathrm{mL})$ exhibited upregulated IL-1 $\beta$ mRNA expression at 3 and 6 hours, and this augmented induction of IL-1 $\beta$ mRNA was largely resolved by 24 hours. As exemplified by the Western blots depicted in Figure 6b, relative to the essentially undetectable levels of IL- $1 \beta$ protein in the membrane lysate samples of human ASM tissues maintained for 24 hours in SFM alone, expression of IL- $1 \beta$ protein was markedly induced in the tissue preparations exposed to IL-5. Finally, in concert with these observations, we also found that IL-5 administration to cultured ASM cells induced a progressive increase in their elaboration of IL- $1 \beta$ protein into the cell culture medium for up to 24 hours (Figure 7; filled bars), whereas IL-1 $\beta$ release was unaltered in cells exposed to SFM alone (Figure 7; open bars). Thus, collectively, these results support the notion of a regulatory role for IL-5 in inducing the upregulated IL-1 $\beta$ mRNA and protein release in the atopic asthmatic sensitized state. 


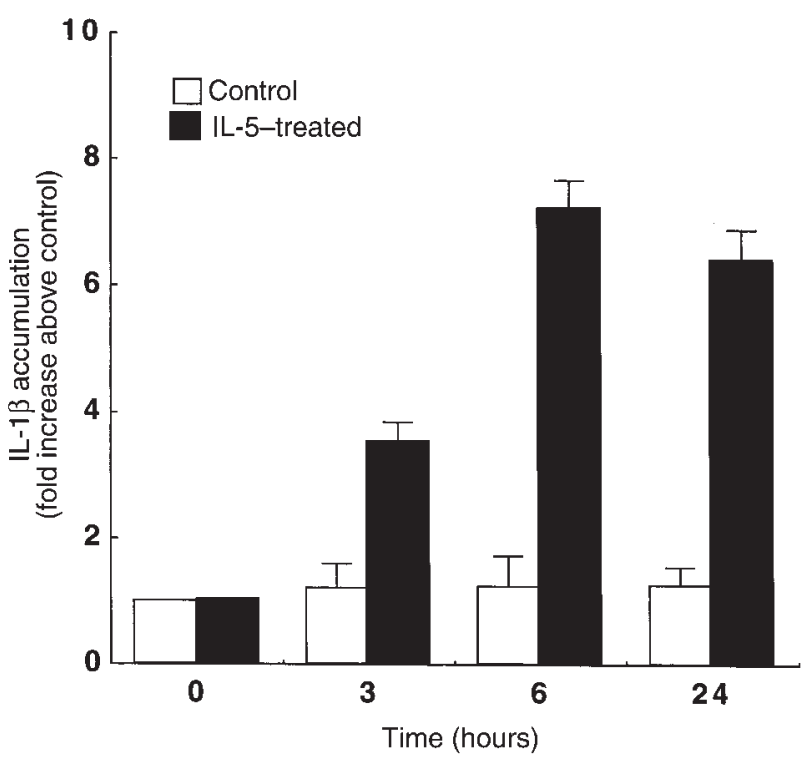

Figure 7

Comparison of human IL-1 $\beta$ protein accumulation in the culture media of human ASM cells after 0-, 3-, 6-, and 24-hour exposure to SFM alone (control; open bars) or IL-5 (filled bars). Relative to unaltered release of IL- $1 \beta$ protein in control cells, ASM cells exposed to IL-5 exhibited significantly increased levels of IL-1 $\beta$ protein release into the cell culture media. Data represent mean \pm SE values.

In view of the aforementioned findings, together with the above pharmacodynamic evidence implicating roles for both IL-5 and IL-1 $\beta$ in mediating the changes in ASM responsiveness in atopic asthmatic sensitized tissues (Figures 1 and 2), we subsequently examined whether the proasthmatic phenotypic changes in ASM responsiveness obtained in the atopic asthmatic sensitized state could be simulated by treating naive ASM with exogenously administered IL-5, and whether any observed IL-5-mediated perturbations in ASM responsiveness are specifically modulated by pretreating the tissues with IL-1ra. Accordingly, in separate paired experiments, constrictor and relaxant dose-response relationships to ACh and isoproterenol, respectively, were compared in ASM exposed for 24 hours to vehicle alone (i.e., control) or to IL-5 in the absence and presence of IL-1ra or IL-4Nab (see Methods). As shown in Figure 8 , relative to their respective controls (open circles), the $\mathrm{T}_{\max }$ responses to ACh were significantly enhanced in tissues treated with a maximally effective concentration of $\mathrm{IL}-5$ ( $5 \mathrm{ng} / \mathrm{mL}$; filled circles), wherein the mean $\pm \mathrm{SE} \mathrm{T}_{\max }$ responses amounted to $135.1 \pm 24.1$ vs. $100.1 \pm 16.8 \mathrm{~g} / \mathrm{g}$ ASM weight in the control ASM $(P<0.05)$. Similarly, the $\mathrm{pD}_{50}$ values for $\mathrm{ACh}$ were significantly enhanced in tissues treated with IL-5, wherein the mean $\pm \mathrm{SE}^{\mathrm{pD}} \mathrm{D}_{50}$ value amounted to $5.11 \pm 0.05$ vs. $4.83 \pm 0.06-\log \mathrm{M}$ obtained in the control tissues $(P<0.05)$. In contrast, as further depicted in Figure 8, in tissues pretreated with IL-1ra, the IL-5-induced changes in ASM constrictor responsiveness to ACh were largely prevented (open squares), and there were no differences between their $\mathrm{T}_{\max }$ and $\mathrm{pD}_{50}$ values and those obtained in correspon- ding control tissues. Moreover, in contrast to its preventative action in IL-5-treated ASM, we found that administration of IL-1ra had no effect on either the $T_{\max }$ or $\mathrm{pD}_{50}$ values obtained in control tissues (data not shown). Finally, pretreatment of control or IL-5-exposed ASM with IL-4Nab had no appreciable effect on the tissues' constrictor responses to ACh (data not shown), a finding consistent with our recent study demonstrating that cultured ASM cells do not express IL-4 protein in either the control or atopic sensitized state (18).

In parallel with the above observations, during similar initial sustained levels of ACh-induced contractions (i.e., $\sim 45 \% \mathrm{~T}_{\max }$ ), the subsequent relaxation responses to cumulative administration of isoproterenol were markedly reduced in IL-5-treated tissues compared with control tissues (Figure 9), wherein the mean \pm SE $\mathrm{R}_{\max }$ responses amounted to $48.8 \pm 4.4$ vs. $61.9 \pm 9.0 \%$, respectively $(P<0.01)$. Similarly, the corresponding $\mathrm{pD}_{50}$ values were also significantly different and averaged $6.21 \pm 0.06$ vs. $6.55 \pm 0.07-\log \mathrm{M}$ in the IL-5-treated vs. control tissues, respectively $(P<0.05)$. Moreover, in accordance with the above observations, whereas IL$4 \mathrm{Nab}$ had no effect, pretreatment with IL-1ra prevented the attenuated ASM relaxant responsiveness to isoproterenol in IL-5-exposed tissues, and there were no differences between their $\mathrm{R}_{\max }$ values and $\mathrm{pD}_{50}$ values and those obtained in control tissues (Figure 9). Finally, in contrast to its effect in IL-5-treated ASM, administration of IL-1ra to control tissues had no effect on either their $\mathrm{R}_{\max }$ or $\mathrm{pD}_{50}$ responses to isoproterenol (data not shown). Taken together, these and the above observations suggest that the nature of the mechanistic interplay between IL-5 and IL-1 $\beta$ in eliciting the proasthmatic perturbations in ASM responsiveness in the atopic asthmatic sensitized state is given by IL5 -induced upregulated expression of IL-1 $\beta$, whereby, as previously described $(17,26)$, the latter cytokine appears to act in an autocrine fashion to mediate the proasthmatic changes in ASM responsiveness (see Discussion).

\section{Discussion}

In recent years, substantial evidence has been accumulated that implicates a predominant $\mathrm{CD}^{+} / \mathrm{Th} 2$ profile of cytokine release in the pathobiology of allergic asthma. In this regard, it has been demonstrated that, relative to nonallergic/nonasthmatic subjects, children and adults with atopic asthma show increased levels of the Th2 2 cytokines IL- 4 and IL-5 in both their serum and bronchoalveolar lavage (BAL) fluid samples (27-32). Moreover, it has been reported that mononuclear cells isolated from serum or BAL fluid samples from atopic asthmatic individuals also demonstrate a relatively enhanced expression of the Th2 phenotype when the cells are stimulated with antigen $(27,30-33)$. Finally, more recent data based on genetic analyses of families with allergic asthma have shown a significant direct correlation between altered airway constrictor responsiveness and IL-4 and IL-5 cytokine levels in serum or BAL fluid samples $(27,33,34)$. 
The roles of the Th2 cytokines in both generating and perpetuating the pulmonary inflammatory response in allergic asthma have been reasonably well characterized. Thus, IL-4 has been found to direct immunoglobulin isotype switching to IgE synthesis, whereas IL-5 appears largely responsible for the maturation, differentiation, recruitment, and effector functions of eosinophils (5-9). Additionally, IL-5 has been implicated in the development of airway constrictor hyperresponsiveness in various animal models of airway sensitization. Accordingly, recent studies have demonstrated that (a) treatment with IL-5 induces airway constrictor hyperresponsiveness (10-12); (b) certain strains of genetically IL-5-deficient mice fail to develop airway eosinophilia and constrictor hyperresponsiveness after allergen challenge in the sensitized state (35); and (c) transgenic mice that constitutively overexpress IL-5 exhibit airway inflammatory changes and constrictor hyperresponsiveness, both of which are pathognomonic of human allergic asthma (36). Notwithstanding this evidence, the mechanism(s) by which IL-5 reportedly elicits the proasthmatic phenotype of altered airway responsiveness remains to be identified. In view of the latter, together with more recent information demonstrating that the ASM itself can be induced to autologously express certain proinflammatory cytokines (notably, IL-1 $\beta$ ) in the atopic asthmatic sensitized state (17), the present study examined the role and mechanism of action of IL-5 in directly regulating ASM responsiveness in the atopic asthmatic sensitized state. Collectively, the results herein provide new evidence demonstrating that (a) IL-5 and IL- $1 \beta$ are endogenously released and mechanistically interact in mediating the proasthmatic-like changes in constrictor and relaxant responsiveness in atopic asthmatic sensitized ASM; and (b) the nature of this interaction is characterized by the initial release of IL-5 by the sensitized ASM, which then induces upregulated expression of IL-1 $\beta$, the latter resulting in an autocrine manifestation of the changes in ASM responsiveness.

To our knowledge, this study is the first to demonstrate that the autologous sequential release of the proinflammatory cytokines IL-5 and IL- $1 \beta$ by atopic asthmatic sensitized ASM results in its autocrine manifestation of altered ASM responsiveness. In addressing the collection of evidence supporting this central finding, certain issues pertaining to the present observations are worthy of consideration. Among these, it is relevant to note that our observed changes in constrictor and relaxant agonist responsiveness in the atopic asthmatic sensitized ASM tissues (Figures 1 and 2) closely mimicked the perturbations in airway function that characterize the in vivo asthmatic condition, including enhanced bronchoconstrictor responsiveness and impaired $\beta$-adrenoceptor-mediated airway relaxation $(17,19)$. Moreover, to the extent that these effects were found to be largely ablated in atopic sensitized ASM that were pretreated with receptor antagonists to either IL-5 or IL-1 $\beta$, these results suggest that both IL-5 and
IL-1 $\beta$ are released by the sensitized ASM and that these cytokines act similarly in ultimately mediating the observed changes in ASM responsiveness. In general, both of these considerations appear to concur with the collection of related information based on other published reports. Accordingly, previous studies have demonstrated that, apart from certain leukocytes, various other non-bone marrow-derived resident tissue cells (e.g., epithelial cells, keratinocytes, etc.) can also elaborate specific cytokines, including Th2-like cytokines (13-16). In this connection, our present observations extend this earlier evidence by demonstrating that ASM cells can also be induced in the atopic sensitized state to autologously express mRNAs for IL-5 and IL-1 $\beta$ (Figure 3 ) and to elaborate these cytokine proteins into the cell culture media (Figure 4). Moreover, regarding the potential roles of IL-5 and IL- $1 \beta$, previous studies that were based on the use of specific neutralizing antibodies or receptor antagonists in in vivo animal models of allergic asthma have independently reported a role for both IL-1 $\beta(17,24-26)$ and IL-5 (10-12) in mediating the observed pulmonary inflammatory responses and altered airway constrictor responsiveness following antigen challenge in the allergen-sensitized state. A priori, these earlier findings seem to be in conflict, because they implicate a role for IL-5 and IL- $1 \beta$ in mediating the proasthmatic phenotype of altered airway responsiveness. Our present observations, however, appear to reconcile this disparity, because they provide evidence in support of mutually inclusive roles for IL-5

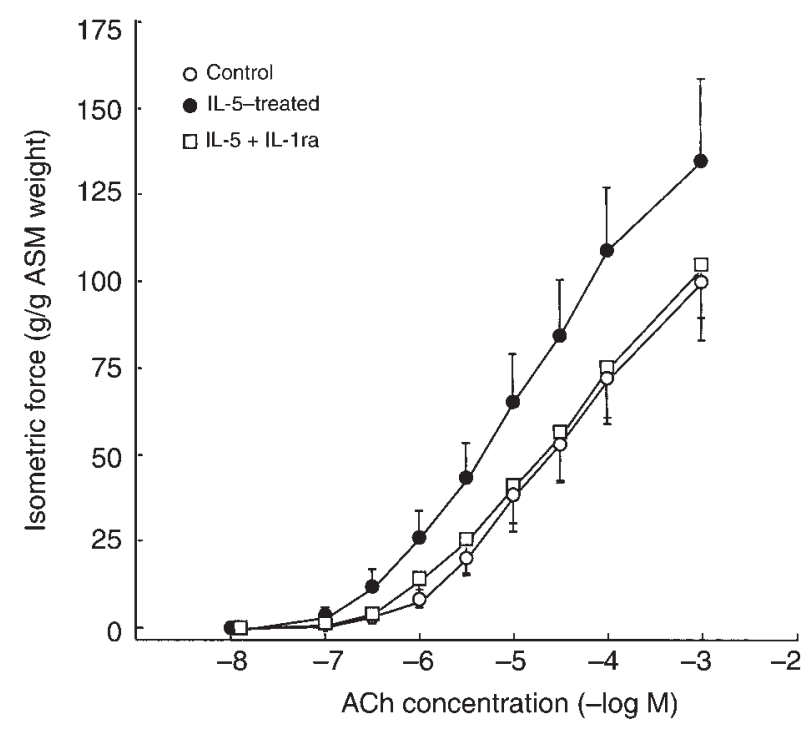

\section{Figure 8}

Comparison of contractile dose-response relationships to ACh in paired rabbit ASM segments after treatment with SFM alone (open circles) or with a maximum effective concentration of IL-5 $(5 \mathrm{ng} / \mathrm{mL})$ in the absence (filled circles) or presence (open squares) of IL-1 ra. Relative to ASM exposed to SFM alone (control), the heightened constrictor responses to ACh in the IL-5-treated tissues were prevented by cotreatment of tissues with IL-1 ra. Data represent mean \pm SE values from 6 paired experiments. 


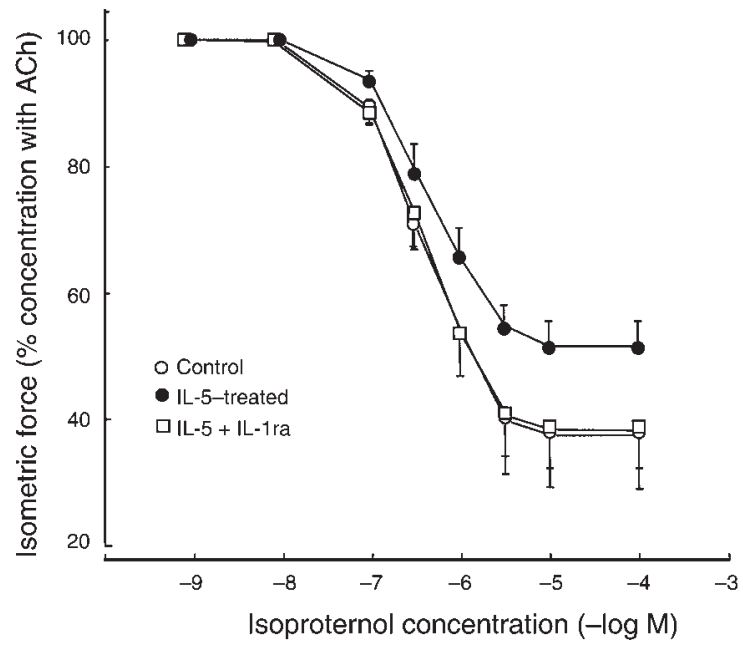

Figure 9

Comparison of relaxation dose-response relationships to isoproterenol in paired rabbit ASM segments half-maximally contracted with their respective $\mathrm{ED}_{50}$ doses of $A C h$ after treatment with SFM alone (open circles) or with IL-5 in the absence (filled circles) or presence (open squares) of IL-1 ra. Relative to ASM exposed to SFM alone (control), the attenuated relaxation responses to isoproterenol in the IL-5-treated tissues were prevented by cotreatment of tissues with IL1ra. Data represent mean \pm SE values from 6 paired experiments.

and IL- $1 \beta$ in mediating the perturbations in ASM responsiveness in the atopic sensitized state (see below).

In addressing the potential mechanism by which IL-5 and IL- $1 \beta$ interact in mediating the observed changes in ASM responsiveness in the atopic sensitized state, our observations in cultured human ASM cells demonstrated that their mRNA expression of both IL-5 and IL$1 \beta$, as well as the release of these cytokine proteins, is upregulated in the atopic sensitized state. Moreover, based on the additional findings demonstrating that the upregulated mRNA expression and release of IL-5 preceded (i.e., by $\sim 3$ hours) the enhanced mRNA expression and release of IL-1 $\beta$ (Figures 3 and 4), the consideration was raised that the initial stimulated release of IL-5 provoked the subsequent elaboration and action of IL-1 $\beta$. Indeed, in support of this concept, our extended observations demonstrated that (a) the enhanced release of IL- $1 \beta$ protein by atopic asthmatic sensitized ASM cells was inhibited when the cells were pretreated with IL-5ra (Figure 5); (b) exogenous administration of IL-5 induced an upregulation of IL- $1 \beta$ mRNA and protein expression in cultured human ASM cells (Figure 6a) and ASM tissue (Figure 6b), as well as an increased elaboration of IL-1 $\beta$ protein into the ASM culture medium (Figure 7); and (c) the proasthmatic-like perturbations in agonist constrictor and relaxant responsiveness obtained after the administration of exogenous IL-5 to naive ASM were prevented in tissues pretreated with IL1ra (Figures 8 and 9, respectively). Taken together, these findings support the notion that our observed effects of IL-5 were largely attributed to its induced autocrine release of IL-1 $\beta$ and the resultant action of the latter cytokine. This concept is, in part, consistent with our previous findings based on studies using the same experimental model described herein. In these studies, we found that the effects on ASM responsiveness of passive sensitization of rabbit ASM with atopic asthmatic serum were attributed to the presence of serum $\operatorname{IgE}$ and its coupled activation of the low-affinity $\operatorname{IgE}$ receptor FceRII (20). Furthermore, under these conditions, the changes in ASM responsiveness in the atopic sensitized state were found to be mediated by the induced autocrine release and action of IL-1 $\beta$ (17). Additionally, we also identified that the effect of IL-1 $\beta$ on ASM responsiveness was largely due to its induced upregulated expression and action of $G_{i}$ protein, specifically $\mathrm{G}_{\mathrm{i}} \alpha_{2}$ and $\mathrm{G}_{\mathrm{i}} \alpha_{3}(26)$, which inhibit intracellular cAMP accumulation (19). Thus, given these earlier findings, when examined in light of the present extended observations, the collection of evidence implicates the presence of an IgE/FceRII-initiated cooperative network of sequential autocrine signaling that involves the release of IL- 5 that, in turn, induces the release of IL- $1 \beta$ by the ASM itself, a process that ultimately results in $\mathrm{G}_{\mathrm{i}}$-mediated perturbations in ASM agonist responsiveness in the atopic asthmatic sensitized state.

To the extent that the present findings pertain to in vitro experimental conditions, the potential role of the above-implicated ASM autocrine cytokine interaction in inducing comparable autologous changes in ASM responsiveness in vivo remains to be identified. Our results, however, may have an important bearing on the possible mechanistic events that relate to the in vivo state. In this connection, it is relevant to note that in a recent study using an in vivo murine model of antigenmediated chronic asthma (37), treatment with an anti-IL-5 mAb (TRFK-5) several days after antigen challenge was found to reverse the existing antigen-induced airway eosinophilia, whereas the antigen-induced airway hyperresponsiveness to methacholine was unaffected by the subsequent administration of TRFK-5. Thus, these data provided evidence that, once established following antigen challenge, the enhanced airway constrictor hyperresponsiveness becomes insensitive to subsequent blockade of IL-5, despite the reversal of airway eosinophilia (37). These in vivo findings, when examined in light of our present observations, provoke the consideration of a potential mechanism by which the manifestation of an IL-5-independent state of altered airway hyperresponsiveness may occur subsequent to initial antigen challenge. Accordingly, our results demonstrate that (a) altered ASM responsiveness in the atopic asthmatic sensitized state is attributable to the activation of an autocrine mechanism that is intrinsic to the sensitized ASM itself; and (b) this mechanism is characterized by an early induction of IL- 5 release that promotes the subsequent release of the pleiotropic proinflammatory cytokine IL-1 $\beta$, which then elicits the observed changes in ASM responsiveness. Taken together, these observations support the notion that, following the initial release of IL- 5 by the sensitized ASM, the tissue's subse- 
quent manifestation of the proasthmatic phenotype represents a phenomenon that is dependent on the secondary induced release and autocrine action of IL-1 $\beta$ and, at this point in the sequence of events, is largely independent of the primary initiating action of IL-5. The presence and contribution of this potential mechanism in the in vivo state, however, remains to be established.

In conclusion, the results of the present study provide new evidence demonstrating that both the Th2 cytokine IL-5 and the pleiotropic proinflammatory cytokine IL$1 \beta$ are endogenously released by atopic asthmatic serum-sensitized ASM, and that these cytokines act cooperatively in mediating the changes in ASM responsiveness in the sensitized state. Furthermore, the results demonstrate that the nature of the latter cytokine interaction is given by the sequential autocrine release of IL5 and IL- $1 \beta$ by the sensitized ASM, wherein the initial endogenous elaboration of IL-5 induces the subsequent elaboration and autocrine action of IL-1 $\beta$. Thus, apart from the conventional concepts related to the roles of various inflammatory cells in the pathogenesis of asthma, the present findings identify a potentially important mechanism by which the resident ASM itself may autologously regulate its own state of altered responsiveness in the atopic asthmatic condition.

\section{Acknowledgments}

We thank J. Grunstein for excellent technical assistance and M. Brown for typing the manuscript. H. Hakonarson was supported as a Parker B. Francis Fellow in Pulmonary Research. This work was supported in part by National Heart, Lung, and Blood Institute grants HL31467 and HL-58245 and by an Institutional Developmental Fund Award from the Joseph Stokes, Jr. Research Institute of the Children's Hospital of Philadelphia.

1. Bai, T.R. 1990. Abnormalities in airway smooth muscle in fatal asthma. Am. Rev. Respir. Dis. 141:552-557.

2. Goldie, R.G., Spina, D., Henry, P.J., Lulich, K.M., and Paterson, J.W. 1986. In vitro responsiveness of human asthmatic bronchus to carbachol, histamine, beta-adrenoceptor agonists and theophylline. Br. J. Clin. Pharmacol. 22:669-676.

3. Bousquet, J., et al. 1990. Eosinophilic inflammation in asthma. N. Engl. J. Med. 323:1033-1039.

4. Djukanovic, R., et al. 1990. Mucosal inflammation in asthma. Am. Rev. Respir. Dis. 142:434-457.

5. Koning, H., Neijens, H.J., Baert, M.R., Oranje, A.P., and Savelkoul, H.F. 1997. T cells subsets and cytokines in allergic and non-allergic children. II. Analysis and IL-5 and IL-10 mRNA expression and protein production. Cytokine. 9:427-436.

6. Gascan, H., et al. 1991. Regulation of human IgE synthesis. Clin. Exp. Allergy. 21(Suppl. 1):162-166.

7. Romagnani, S. 1995. Biology of human TH1 and TH2 cells. J. Clin. Immunol. 15:121-129.

8. Tavernier, J.H., et al. 1996. In Hematopoetic cell growth factors and their receptors. A.D. Whetton and J. Gordon, editors. Plenum Press. New York, NY. 321-361.

9. Shimoda, K., et al. 1996. Lack of IL-4-induced Th2 response and IgE class switching in mice with disrupted Stat6 gene. Nature. 380:630-633.

10. Foster, P.S., Hogan, S.P., Ramsay, A.J., Matthaei, K.I., and Young, I.G. 1996. Interleukin 5 deficiency abolishes eosinophilia, airways hyperreactivity, and lung damage in a mouse asthma model. J. Exp. Med. 183:195-201.

11. Hall, L.R., Mehlotra, R.K., Higgins, A.W., Haxhiu, M.A., and Pearlman, E. 1998. An essential role for interleukin-5 and eosinophils in helminthinduced airway hyperresponsiveness. Infect. Immun. 66:4425-4430.

12. Till, S.J., et al. 1998. Allergen-induced proliferation and interleukin-5 production by bronchoalveolar lavage and blood T cells after segmental allergen challenge. Am. J. Respir. Crit. Care Med. 158:404-411.

13. Stadnyk, A.W. 1994. Cytokine production by epithelial cells. FASEB J. 8:1041-1047.

14. Luger, T.A., et al. 1990. Cytokines and the skin. Curr. Probl. Dermatol. 19:35-49.

15. Jordana, M., Sarnstrand, B., Sime, P.J., and Ramis, I. 1994. Immuneinflammatory functions of fibroblasts. Eur. Respir. J. 7:2212-2222.

16. Barker, J.N., Mitra, R.S., Griffiths, C.E., Dixit, V.M., and Nickoloff, B.J. 1991. Keratinocytes as initiators of inflammation. Lancet. 337:211-214.

17. Hakonarson, H., Herrick, D.J., Serrano, P.G., and Grunstein, M.M. 1997. Autocrine role of interleukin 1beta in altered responsiveness of atopic asthmatic sensitized airway smooth muscle. J. Clin. Invest. 99:117-124.

18. Hakonarson, H., Maskeri, N., Carter, C., and Grunstein, M.M. 1999. Regulation of TH1- and TH2-type cytokine expression and action in atopic asthmatic sensitized airway smooth muscle. J. Clin. Invest. 103:1077-1087.

19. Hakonarson, H., Herrick, D.J., and Grunstein, M.M. 1995. Mechanism of impaired beta-adrenoceptor responsiveness in atopic sensitized airway smooth muscle. Am. J. Physiol. 269:L645-L652.

20. Hakonarson, H., and Grunstein, M.M. 1998. Autologously up-regulated Fc receptor expression and action in airway smooth muscle mediates its altered responsiveness in the atopic asthmatic sensitized state. Proc. Natl. Acad. Sci. USA. 95:5257-5262.

21. Campbell, H.D., et al. 1987. Molecular cloning, nucleotide sequence, and expression of the gene encoding human eosinophil differentiation factor (interleukin 5). Proc. Natl. Acad. Sci. USA. 84:6629-6633.

22. Conlon, P.J., III, Cosman, D.J., Grabstein, D.J., Mopp, T.P., Kronham, S.R., Larsen, A.D., March, C.J., Price, V.L., and Current, D.P., inventors. Gene encoding biologicallyactive human interleukin 1 . US patent 5,122,459. Issued June 16, 1992.

23. Seshadri, T., Uzman, J.A., Oshima, J., and Campisi, J. 1993. Identification of a transcript that is down-regulated in senescent human fibroblasts. Cloning, sequence analysis, and regulation of the human L7 ribosomal protein gene. J. Biol. Chem. 268:18474-18480.

24. Watson, M.L., Smith, D., Bourne, A.D., Thompson, R.C., and Westwick, J. 1992. Cytokines contribute to airway dysfunction in antigen-challenged guinea pigs: inhibition of airway hyperreactivity, pulmonary eosinophil accumulation, and tumor necrosis factor generation by pretreatment with an interleukin-1 receptor antagonist. Am. J. Respir. Cell Mol. Biol. 8:365-369.

25. Wills-Karp, et al. 1993. Organ culture with proinflammatory cytokines reproduces impairment of the beta-adrenoceptor-mediated relaxation in tracheas of a guinea pig antigen model. Am. J. Respir. Cell Mol. Biol. 8:153-159.

26. Hakonarson, H., Herrick, D.J., Serrano, P.G., and Grunstein, M.M. 1996. Mechanism of cytokine-induced modulation of beta-adrenoceptor responsiveness in airway smooth muscle. J. Clin. Invest. 97:2593-2600.

27. Robinson, D.S., et al. 1992. Predominant TH2-like bronchoalveolar Tlymphocyte population in atopic asthma. N. Engl. J. Med. 326:298-304.

28. Walker, C., et al. 1992. Allergic and nonallergic asthmatics have distinct patterns of T-cell activation and cytokine production in peripheral blood and bronchoalveolar lavage. Am. Rev. Respir. Dis. 146:109-115.

29. Ackerman, V., et al. 1994. Detection of cytokines and their cell sources in bronchial biopsy specimens from asthmatic patients. Relationship to atopic status, symptoms, and level of airway hyperresponsiveness. Chest. 105:687-696.

30. Hamid, Q., et al. 1991. Expression of mRNA for interleukin-5 in mucosal bronchial biopsies from asthma. J. Clin. Invest. 87:1541-1546.

31. Ying, S., Durham, S.R., Corrigan, C.J., Hamid, Q., and Kay, A.B. 1995. Phenotype of cells expressing mRNA for TH2-type (interleukin 4 and interleukin 5) and TH1-type (interleukin 2 and interferon gamma) cytokines in bronchoalveolar lavage and bronchial biopsies from atopic asthmatic and normal control subjects. Am. J. Respir. Cell Mol. Biol. 12:477-487.

32. Robinson, D., et al. 1993. Prednisolone treatment in asthma is associated with modulation of bronchoalveolar lavage cell interleukin-4, interleukin-5, and interferon-gamma cytokine gene expression. Am. Rev. Respir. Dis. 148:401-406.

33. Umetsu, D.T., and DeKruyff, R.H. 1997. Th1 and Th2 CD4+ cells in the pathogenesis of allergic diseases [review]. Proc. Soc. Exp. Biol. Med. 215:11-20.

34. Zangrilli, J.G., et al. 1995. sVCAM-1 levels after segmental antigen challenge correlate with eosinophil influx, IL-4 and IL-5 production, and the late phase response. Am. J. Respir. Crit. Care Med. 151:1346-1353.

35. Foster, P.S., Hogan, S.P., Ramsay, A.J., Matthaei, K.I., and Young, I.G. 1996. Interleukin 5 deficiency abolishes eosinophilia, airways hyperreactivity, and lung damage in a mouse asthma model. J. Exp. Med. 183:195-201.

36. Lee, J.J., et al. 1997. Interleukin-5 expression in the lung epithelium of transgenic mice leads to pulmonary changes pathognomonic of asthma. J. Exp. Med. 185:2143-2156.

37. Mathur, M., et al. 1999. TRFK-5 reverses established airway eosinophilia but not established hyperresponsiveness in a murine model of chronic asthma. Am. J. Respir. Crit. Care Med. 159:580-587. 